\title{
Effect of rate of application on degradation of imazethapyr in groundnut and soil under tropical Indian condition
}

\author{
C. Babu ${ }^{1}, *$ P. Janaki ${ }^{2}$ and C. Chinnusamy ${ }^{3}$ \\ University, Coimbatore- 641003, INDIA \\ *Corresponding author. E-mail: janakibalamurugan@rediffmail.com \\ Received: March 12, 2015; Revised received: July 21, 2015; Accepted: September 10, 2015
}

All India Coordinated Research Project on Weed Control, Department of Agronomy, Tamil Nadu Agricultural

\begin{abstract}
Pesticides though formulated to be biologically degradable, few herbicides reported to cause surface and groundwater contamination which needs the monitoring of herbicide residues in environment continuously. Thus, to monitor the persistence and residues in crops, imazethapyr degradation studies were conducted in soil with groundnut cropping under Indian tropical condition. A groundnut field was treated with different doses of imazethapyr as early post emergence. Results showed that the degradation of imazethapyr in soil and groundnut plant followed first order reaction kinetics irrespective of the dose. The residue of imazethapyr persists in soil up to 60 days at higher rates of application while it persists up to 30 days in plant with the calculated half life of 2.8 to 7.4 days in soil and 5.1 to 5.9 days in plant. At the time of harvest, the residue of imazethapyr in soil, groundnut haulm or pods were below the detectable limit of $0.008 \mathrm{mg} / \mathrm{kg}$ across different doses of application. However, the continuous and inappropriate use in light textured soils may cause groundwater contamination and bioaccumulation in plant system. Hence, a pre harvest interval of 75 days must be allowed after the application of imazethapyr for the weed control in groundnut.
\end{abstract}

Keywords: Groundnut, HPLC, Imazethapyr, Persistence, Soil

\section{INTRODUCTION}

Groundnut (Arachis hypogaea L.), the "King”" of oilseeds, popularly known as "Wonder nut " and "Poor man's cashew nut" is the sixth most important oilseed crop of the world. In the National scenario, Tamil Nadu shares 8.59 per cent in area and 11.44 per cent in production of the crop (Agricultural Statistics, 2009). One of the major constraints in groundnut production is the weed menace and weeds cause considerable yield loss in field crops by competing for biotic and abiotic factors. With the advent of herbicide technology, a number of herbicides with high potency and economic are available for effective control of weeds in field crops. The selection of herbicides depends on the crop, variety, crop growth stage, condition of the foliage, soil type and weed flora present in the field (Davies and Welsh, 2002).

One of the recently registered herbicides in India for groundnut is imazethapyr which belongs to a class of chemicals known as imidazolinones and the IUPAC name is [5-ethyl-2-(4-isopropyl-4-methyl-5-oxo-2 -imidazolinoxo-2-imidazolin-2-yl) nicotinic acid. This class has a very specific mode of action inhibiting certain plant systems, but does not interact in animals (Vencil, 2002). Imidazolinone herbicides have become widely used because of their low application rates, reduced environmental impact and selectivity in a wide range of cropping systems. They are applied either pre- or post-emergence, as selective herbicides for broad spectrum control of broadleaf weeds and grasses in soybean [Glycine $\max ($ L.) Merr.] and several other leguminous crops (Barkani et al., 2005). It has both soil and foliar activity (Stougaard et al., 1990) and is absorbed through roots and foliage and translocated in both xylem and phloem and thereby accumulated in plants at growing points.

Imazethapyr is an amphoteric herbicide, having a carboxylic acid and a basic pyridine functional group (Stougaard et al., 1990) and this property allows the herbicide to be in anionic, neutral or cationic states depending upon the $\mathrm{pH}$ of the environment (Stougaard et al., 1990; Pusino et al., 1997). Because of the specific molecular structure, soil factors such as $\mathrm{pH}$, organic carbon content, and ionic strength may affect its persistence in the environment (Johnson et al., 2000). The imidazolinone herbicides are relatively persistent in soil with half-lives ranging from 30 to 150 days and may have carryover effect to the rotational crops (Goetz et al., 1990; Curran et al., 1992). Given the persistent nature of these herbicides on some soil types, it is important to investigate the mechanism responsible for imazethapyr degradation. Such information will assist in developing guidelines to prevent damage by imazethapyr residues on sensitive crops grown in the rotation or sequence. Although herbicides are designed to target plants, they can also be toxic to humans and wildlife. Herbicides vary greatly in their environmental impact, and more specifically, their 
toxicity and persistence in the environment. Little work has been done on the persistence and degradation of imazethapyr in Indian tropical condition mostly with soybean (Patel et al. 2009; Sondhia, 2014) and no work has been reported on the groundnut. Hence the present study was undertaken to investigate the field degradation behavior of imazethapyr in groundnut crop and soil under tropical condition of India.

\section{MATERIALS AND METHODS}

Field experiments: The present study was carried out during kharif season of 2009 and 2010 at Agricultural Research Station, Bhavanisagar, Tamil Nadu Agricultural University. The experiments were laid out in randomized complete block design with five treatments (each plot size was $30 \mathrm{~m}^{2}$ ) and replicated thrice. The treatments consisted of four doses of imazethapyr $10 \%$ soluble liquid (SL) viz., 75, 100, 150 and $200 \mathrm{~g} \mathrm{ha}^{-1}$ followed by one hand weeding at 45 days after sowing (DAS) and the control. The kharif groundnut variety CO 2 was sown manually at a spacing of $30 \times 10 \mathrm{~cm}$ with $125 \mathrm{~kg}$ $\mathrm{ha}^{-1}$ of seeds. The experimental field was irrigated immediately after sowing. Life irrigation was given three days after sowing and subsequent irrigations were given as and when required. Imazethapyr 10\% SL was sprayed at 2-3 leaf stage of weeds (15 DAS) as early post emergence followed by a hand weeding and earthing up on 45 DAS. Calculated quantity of herbicides with a spray fluid of 500 liters $\mathrm{ha}^{-1}$ was sprayed uniformly over the plots using knapsack sprayer fitted with fan type nozzle. A fertilizer schedule of 17:34:54 kg $\mathrm{N}, \mathrm{P}_{2} \mathrm{O}_{5}, \mathrm{~K}_{2} \mathrm{O} \mathrm{ha}^{-1}$ in the form of urea, single super phosphate and muriate of potash, respectively were applied to all plots uniformly in lines and incorporated at the time of sowing. The entire dose of NPK was applied as basal. Gypsum at the rate of $400 \mathrm{~kg} \mathrm{ha}^{-1}$ was applied in two equal splits, one at basal and another at the time of earthing up (45 DAS). The experimental field soil was red sandy loam in texture, low in available nitrogen (221 kg ha-1), medium in available phosphorus $\left(16.2 \mathrm{~kg} \mathrm{ha}^{-1}\right)$ and high in available potassium (288 kg ha $\left.{ }^{1}\right)$ with $\mathrm{pH}$ of 7.5 and organic carbon of 0.52 per cent.

Soil and plant samples collection: Soil samples were collected from the imazethapyr treated plots at intervals of 0 ( $2 \mathrm{hrs}$ after herbicide application), 5, 15, 30 and 45 days after herbicide application (DAHA) and at harvest and analyzed for imazethapyr residue content. About 2 $\mathrm{kg}$ of five-soil cores were randomly taken from each treated and untreated plot avoiding the outer $0.5 \mathrm{~m}$ of the plots using a soil auger up to a depth of $15 \mathrm{~cm}$ from the surface. Pebbles and other unwanted materials were removed manually. The cores were bulked together from each plot, well mixed and stored in polythene bags at $-10^{\circ} \mathrm{C}$ until sample extraction. Samples from the control plots were collected before the herbicide treated plots for residue analysis.

Plant samples were collected from the imazethapyr treated plots at periodical intervals of $0(2 \mathrm{hrs}$ after herbicide application), 5, 15, 30, 45 and 60 DAHA and at harvest. About $500 \mathrm{~g}$ of representative plant samples were collected from imazethapyr treated and untreated plots. The plant samples were cut into small pieces and then ground on mechanical grinder and used for residue analysis. Plant samples were stored at $-15^{\circ} \mathrm{C}$ until processed for residue extraction.

Imazethapyr extraction and analysis: The protocol suggested by Ascenzo et al. (1998) was followed for the extraction of imazethapyr from the soil sample using potassium chloride $(0.1 \mathrm{M} \mathrm{KCl})$ and by shaking the mixture for 10 minutes in a mechanical shaker. The residue was re-dissolved in $2 \mathrm{ml}$ of $0.1 \mathrm{M} \mathrm{KCl}$ for HPLC analysis. Similarly the procedure given by Szmigielska and Schoenau (1999) was followed for the imazethapyr residue extraction from plants using $50 \mathrm{ml}$ of 90 per cent methanol/ water $(\mathrm{v} / \mathrm{v})$ and residue was re-dissolved in $2 \mathrm{ml}$ of methanol for HPLC determination.

Instrumental conditions: Imazethapyr residues were determined by Agilent HPLC (1200 series) equipped with Diode Array Detector (DAD) detector, Binary pump and auto sampler with Rheodyne injection system. The separation of compounds was performed using Agilent Eclipse XDB - C 18, $5 \mu \mathrm{m}, 4.6 \times 150$ $\mathrm{mm}$ column kept in thermo stated oven maintained at $25^{\circ} \mathrm{C}$. The instrument was connected to a computer which records the response in terms of peak area and height using the EZChrom software. The mobile phase used for the determination of imazethapyr was methanol: distilled water: acetic acid (40:59:1v/v). The injection volume of sample was $20 \mu \mathrm{l}$ and the flow rate of mobile phase was $1.0 \mathrm{ml} \mathrm{min}^{-1}$. Detection was performed at $236 \mathrm{~nm}$ for all the unknown samples since the interferences were minimal at these wavelengths. The retention time of imazethapyr standards and samples under the above instrumental conditions was $4.79 \pm 0.2 \mathrm{~min}$. A calibration curve was prepared by plotting concentrations of imazethapyr on $\mathrm{X}$ -axis against the average peak area on Y-axis.

Method validation and detection limits: Validation of method was executed in terms of recovery studies before analyzing unknown samples as suggested by Janaki et al. (2013) for oxyfluorfen in onion using the standards 0.01 to $1.0 \mu \mathrm{g} \mathrm{mL}^{-1}$ of imazethapyr. The extraction and cleanup processes were then performed as described in the methodology for samples. Quantification of imazethapyr residue was accomplished by comparing the peak response for samples with peak area of the standards.

Degradation kinetics: The degradation and half life of a molecule was calculated using first order kinetics equation: $\mathrm{dA} / \mathrm{dt}=\mathrm{Ka} \rightarrow \mathrm{A}(\mathrm{t})=\mathrm{A}_{\mathrm{o}}$ exp. Where $\mathrm{A}$ is herbicide amount, $t$ is time, $A_{o}$ is the initial amount and $\mathrm{k}$ is degradation coefficient. The half life of the herbicide molecules were determined from the equation $\mathrm{T}_{1 / 2}=$ $(0.6931 / \mathrm{k})$ using the highest concentration.

\section{RESULTS AND DISCUSSION}

Under the given conditions of HPLC-DAD, imazethapyr resolved at $4.65 \mathrm{~min}$ as a single sharp 
Table 1. Persistence of imazethapyr $\left(\mu \mathrm{g} \mathrm{g}^{-1}\right)$ in field soil (mean of 2 season results).

\begin{tabular}{|c|c|c|c|c|}
\hline \multirow{2}{*}{$\begin{array}{c}\text { Days after last } \\
\text { application }\end{array}$} & \multicolumn{4}{|c|}{ Dose of imazethapyr applied in soil } \\
\hline & $75 \mathrm{~g} \mathrm{ai} \mathrm{ha}^{-1}$ & $100 \mathrm{~g} \mathrm{ai} \mathrm{ha}^{-1}$ & $150 \mathrm{~g} \mathrm{ai} \mathrm{ha}^{-1}$ & $200 \mathrm{~g} \mathrm{ai} \mathrm{ha}^{-1}$ \\
\hline 0 & $0.550 \pm 0.014(-)$ & $0.902 \pm 0.016(-)$ & $1.310 \pm 0.012(-)$ & $2.090 \pm 0.017(-)$ \\
\hline 5 & $0 . .108 \pm 0.013(80.4)$ & $0.350 \pm 0.017(61.2)$ & $0.670 \pm 0.011(55.3)$ & $1.181 \pm 0.015(43.5)$ \\
\hline 15 & $0.023+0.011(97.6)$ & $0.045 \pm 0.019(90.0)$ & $0.176 \pm 0.015(88.3)$ & $0.430 \pm 0.014(79.4)$ \\
\hline 30 & BDL & 0.018 & $0.049 \pm 0.015(96.7)$ & $0.180 \pm 0.014(91.4)$ \\
\hline 45 & BDL & BDL & $0.016 \pm 0.009(98.9)$ & $0.025 \pm 0.011(98.8)$ \\
\hline 60 & BDL & BDL & BDL & BDL \\
\hline 90 & BDL & BDL & BDL & BDL \\
\hline
\end{tabular}

$\mathrm{SD}$ - Standard deviation; BDL- below Detectable Limit $<0.008 \mathrm{ppm}\left(\mu \mathrm{g} \mathrm{g}^{-1}\right) ; *$ Mean of three replications; Values in parenthesis are the dissipation rate $(\%)$ of imazethapyr

Table 2. Persistence of imazethapyr $\left(\mu \mathrm{g} \mathrm{g}^{-1}\right)$ in groundnut plant (mean of 2 season results).

\begin{tabular}{|c|c|c|c|c|}
\hline \multirow{2}{*}{$\begin{array}{l}\text { Days after last } \\
\text { application }\end{array}$} & \multicolumn{4}{|c|}{ Dose of imazethapyr applied in soil } \\
\hline & $75 \mathrm{~g} \mathrm{ai} \mathrm{ha}^{-1}$ & $100 \mathrm{~g}_{\text {ai ha }}{ }^{-1}$ & 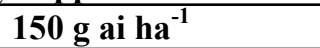 & $200 \mathrm{~g}_{\text {ai ha }}{ }^{-1}$ \\
\hline 0 & $0.023 \pm 0.011(-)$ & $0.033 \pm 0.011(-)$ & $0.045 \pm 0.009(-)$ & $0.056 \pm 0.013(-)$ \\
\hline 5 & $0.011 \pm 0.009(52.2)$ & $0.013 \pm 0.006(60.6)$ & $0.023 \pm 0.008(40.1)$ & $0.045 \pm 0.008(39.3)$ \\
\hline 15 & BDL & BDL & $0.009 \pm 0.0007(80.0)$ & $0.012 \pm 0.004(78.6)$ \\
\hline 30 & BDL & $\mathrm{BDL}$ & $\mathrm{BDL}$ & $\mathrm{BDL}$ \\
\hline 45 & $\mathrm{BDL}$ & BDL & $\mathrm{BDL}$ & BDL \\
\hline
\end{tabular}

SD - Standard deviation; BDL- Below Detectable Limit $<0.008 \mathrm{ppm}\left(\mu \mathrm{g} \mathrm{g}^{-1}\right)$; ${ }^{*}$ Mean of three replications; Values in parenthesis are the dissipation rate (\%) of imazethapyr

Table 3. Optimized first order field dissipation curves as influenced by quantity of application.

\begin{tabular}{cccc}
\hline $\begin{array}{l}\text { Imazethapyr dose } \\
\text { (g ai / ha) }\end{array}$ & DT $\mathbf{5 0}$ & Predicted equation & Goodness of fit \\
\hline & & Field soil & $\mathrm{R}^{2}=0.986$ \\
75 & 2.83 & $\mathrm{y}=6.161-0.246 \mathrm{x}$ & $\mathrm{R}^{2}=0.999$ \\
100 & 3.44 & $\mathrm{y}=6.838-0.202 \mathrm{x}$ & $\mathrm{R}^{2}=0.985$ \\
150 & 6.32 & $\mathrm{y}=7.060-0.110 \mathrm{x}$ & $\mathrm{R}^{2}=0.983$ \\
200 & 7.43 & $\mathrm{y}=7.613-0.093 \mathrm{x}$ & $\mathrm{R}^{2}=0.999$ \\
& & Groundnut plant & $\mathrm{R}^{2}=0.966$ \\
75 & 5.14 & $\mathrm{y}=3.118-0.136 \mathrm{x}$ & $\mathrm{R}^{2}=0.999$ \\
100 & 5.68 & $\mathrm{y}=3.375-0.122 \mathrm{x}$ & $\mathrm{R}^{2}=0.996$ \\
\hline
\end{tabular}

peak. The Instrument Detection Limit (IDL) for imazethapyr was $0.05 \mu \mathrm{g} \mathrm{mL}^{-1}$, and the calibration curve was linear $\left(\mathrm{r}^{2}=0.981\right)$ from 0.05 to $1.0 \mu \mathrm{g} \mathrm{mL}^{-1}$. The estimated method detection limit (EMDL) by this method using equation was found to be $0.008 \mu \mathrm{g} \mathrm{g}^{-1}$ of both soil and plant parts. Average recovery of imazethapyr from spiked soil and groundnut plant samples were 92 and 89 per cent, respectively.

An application of imazethapyr was done as early post emergence to control weeds in the groundnut cropped field at four rates viz., 75, 100, 150 and $200 \mathrm{~g}^{\text {ai ha }}{ }^{-1}$. Residues were monitored up to harvest after its last application. The concentration of imazethapyr gradually decreased at all the doses of application with the advancement of crop growth. On day 0 , initial deposit of imazethapyr residue determined was ranged from 0.550 to $2.02 \mu \mathrm{g} \mathrm{g}^{-1}$ of soil across different levels of application (Table 1). Increase in initial deposition with increased dose of herbicides has been reported by many authors under different situations (Janaki et al. 2009; Sondhia, 2013). At rates of 75 and $100 \mathrm{~g}^{\text {ai ha }}{ }^{-1}$, 100 per cent of the imazethapyr residues dissipated from soil on day 30 of application. At rates of 150 and $200 \mathrm{~g}$ ai ha ${ }^{-1}$, imazethapyr dissipated slowly from soil, and 55 and $44 \%$ dissipation was observed, respectively, on day 5 after last application and on day 30, more than $90 \%$ was dissipated from the soil irrespective of dose of application. On day $45,100 \%$ of the initial 
deposit dissipated from soil at all the rates of application and becomes below detection limit (BDL) except at $200 \mathrm{~g}$ ai ha ${ }^{-1}$. This could be ascribed to the enhanced microbial degradation which is a primary process that determines the rate of degradation of imidazolinones in soils and is again induced by the concentration of herbicide in soil solution (Flint and Witt, 1997). Photodecomposition is another major dissipation mechanism for Imazethapyr and Curran et al. (1992) reported that the imidazolinones are prone to degradation when they remain exposed to light on the soil surface in field. The imazethapyr losses through photo degradation were found to be 2 to $52 \%$ across different surfaces (Goetz et al., 1990). Since the present experimental field soil was low in organic matter content, the degradation was faster due to the poor adsorption and enhanced microbial and photo degradation. Loux and Reese (1993) reported that the persistence of the imazethapyr decreased with increase in soil $\mathrm{pH}$ depending on the soil type. Ahmad et al. (2001) reported that the organic matter, $\mathrm{pH}$ and time are important factors that determine how tightly the imidazolinones are sorbed to the soil and its degradation further. The imazethapyr dissipation was enhanced in the present study since it exists as anionic form at the present soil $\mathrm{pH}$ of 7.2. This was in line with the findings of Stougaard et al. (1990) who stated that the presence of anionic form of imazethapyr at $\mathrm{pH}$ greater than $\mathrm{pKa}$, causes it to be repulsed by the soil colloids which leads to low sorption in neutral or high soil $\mathrm{pH}$. Harvest soil was also analyzed, and found the residues of imazethapyr were below detectable limits.

The residue of imazethapyr in ground nut plant was determined from 0 days after its application onwards. On day 0 , the imazethapyr concentration detected was as $0.023,0.033,0.045$ and $0.056 \mu \mathrm{g} \mathrm{g}^{-1}$ of plant at 75 , 100,150 and $200 \mathrm{~g}^{\text {ai }} \mathrm{ha}^{-1}$ respectively. On day 5, decrease in imazethapyr residue concentration was observed (Table 2). On day 15, the imazethapyr residue in plant becomes BDL at the lower doses of 75 and $150 \mathrm{~g}$ a.i. ha $^{-1}$ while it tooks 30 days at the higher doses. However, more than 75 per cent of the initial concentration dissipated on 15 days after application.

The rate of disappearance of imazethapyr in soil followed first-order kinetics. The data fitted well the regression equations with $\mathrm{R}^{2}$ values of more than 0.97 across different levels of application (Table 3 ). The increase in dose of application increased the half life in soil and was found to be ranged between 2.83 to 7.43 days at the four rates of application. However, the half life of 30 days under lab condition and 60 days under field condition was reported for imazethapyr by Flint and Witt (1997) and Mills and Witt (1989). Such a shorter half life of imazethapyr in the present study might have been due to the enhanced photolysis by the high temperature and sun shine hours prevailed during the early crop growth period. Added to this, the high solubility of imazethapyr in water might have increased its movement from the present sandy clay loam soil and similar results was reported by Wyk and Reinhard (2001) that the imzathapyr leached beyond $30 \mathrm{~cm}$ depth in sandy textured soils depending upon the amount of rainfall. Sondhia (2013) also found that the imazethapyr could be leached up to $70 \mathrm{~cm}$ depth in clay loam soil under continuous and high rainfall conditions.

The dissipation rate of imazethapyr in groundnut plant was fast and this could be attributed to the dilution of residue concentration in plant by the higher growth rate. The half-life values of imazethapyr calculated from the regression equation were found to be ranged between 5.14 to 5.68 days at the four rates of application. Influence of dose of application on the half life and persistence of imazethapyr in groundnut plant was not observed in this study. Half life, correlation coefficient and regression equations for each dose are given in table 2. At the time of harvest, haulm and pods were collected from the field were analyzed, and found that the residue of imazethapyr was below detectable limits $\left(0.05 \mathrm{mg} \mathrm{kg}^{-1}\right)$. Similar result was reported by Patel et al. (2009) in soybean and stover, however the field soil at the time of soybean harvest had residue of imazethapyr above $0.01 \mathrm{mg} / \mathrm{kg}$. The present study revealed that residues of imazethapyr in soil and groundnut plant were below the maximum residue limits set by European countries $(0.1 \mathrm{mg} / \mathrm{kg})$. Since it persist in soil up to 60 days and there may a chance for the bioaccumulation in plant through plant uptake. Hence, a pre harvest interval of 75 days must be allowed after the application of imazethapyr for weed control in groundnut.

\section{Conclusion}

It is concluded that the residue of imazethapyr persists in soil up to 45 days at higher rates of application and upto 15 days in groundnut plant. At the time of harvest, no residue of imazethapyr was detected in soil, groundnut haulm or pods and is well below the maximum residue limit of $0.1 \mathrm{mg} / \mathrm{kg}$ set by the European Union. However the continuous and inappropriate use of this herbicide under long run in light textured soils may become a problem for groundwater contamination. Since it persists in soil up to 60 days, there may be a chance for the bioaccumulation in plant through plant uptake. Hence, a pre harvest interval of 75 days must be allowed after the application of imazethapyr for weed control in groundnut.

\section{ACKNOWLEDGEMENT}

Authors thank the Department of Agronomy, Tamil Nadu Agricultural University, Coimbatore and Directorate of Weed Science Research, Jabalpur for allowing to work in the lab and availing the infrastructual facilities.

\section{REFERENCES}

Agricultural Statistics (2009). Agricultural Statistics at a glance. Directorate of Economics and Statistics. Dept. of Agric. and Co-operation. Ministry of Agriculture, Government of India

Ahmad, R., Kookana, R.S. and Alston, A.M. (2001). Sorp- 
tion of ametryn and imazethapyr in twenty-five soils from Pakistan and Australia. J. Environ. Sci.Health, B. 26:143-160.

Ascenzo, G.D., Gentili, A., Marchese, S., Marino, A. and Perret, D. (1998). Rapid and simple method for extraction and determination of imidazolinone herbicides in soil. Analysis, 26(7): 251-255

Barkani, H., Catastini, C. and Emmelin, M. (2005). Study of the photo transformation of imazaquin in aqueous solution: A kinetic approach. J. Photochem. Photobiol., A: Chem., 170:27-35

Curran, V.S., Liebl, R. and Simmons, F.W. (1992). Effects of tillage and application method on clomazone, imazaquin and imazethapyr persistence. Weed Sci., 40:482489

Davies, D.H.K. and Welsh, J.P. (2002). Weed control in organic cereals and pulses In: D. Younie, B.R. Taylor, J.M. Welch and J.M. Wilkinson Edn. Organic cereals and pulses. Chapter 5, Chalcombe public. p.77-114

Flint, J.L. and Witt, W.W. (1997). Microbial degradation of imazaquin and imazethapyr. Weed Sci., 45:586-591

Goetz, A.J., Lavy, T.L. and Gbur, E.E. (1990). Degradation and field persistence of imazethapyr. Weed Sci,. 38: $421-428$

Janaki, P., Sathya Priya, R. and Chinnusamy, C. (2013). Field dissipation of oxyfluorfen in onion and its dynamics in soil under Indian tropical conditions, Journal of Environmental Science and Health, Part B: Pesticides, Food Contaminants, and Agricultural Wastes, 48:11, 941-94

Johnson, D.H., Shaner, D.L., Deane, J. (2000). Mackersie L.A. and Tuxhorn G., Time-dependent adsorption of imazethapyr to soil. Weed Sci., 48:769-775

Loux, M.M. and Reese, K.D. (1993). Effect of soil type and
$\mathrm{pH}$ on persistence and carryover of imidazolinone herbicides. Weed Technol., 7:452-458

Mills, J.A. and Vitt, W.W. (1989). Efficacy, phytotoxicity and persistence of imazaquin, imazethapyr and clomazone in no-till double-crop soybeans (Glycine max). Weed Sci., 37:353-359

Patel, R.K; Sondhia, S. and Dwivedi, A.K. (2009). Residues of imazethapyr in soybean grain, straw and soil under application of long term fertilizers in Typic Haplustert. Indian Journal of Weed Science 41(1\&2): 90-92.

Pusino, A., Petretto, S. and Gessa, C. (1997). Adsorption and desorption of imazapyr by soil. J. Agric. Food Chem., 45:1012-1016

Sondhia, S. (2013). Evaluation of imazethapyr leaching in soil under natural rainfall conditions. Indian Journal of Weed Science 45 (1): 58-61.

Sondhia, S. (2014). Herbicides residues in soil, water, plants and non-targeted organisms and human health implications: an Indian perspective. Indian Journal of Weed Science, 46 (1): 66-85.

Stougaard, R.N., Shea, P.J. and Martin, A.R. (1990). Effect of soil type and $\mathrm{pH}$ on adsorption, mobility and efficacy of imazaquin and imazethapyr. Weed Sci., 38: 67-73

Szmigielska, A.M. and Schoenau, J.J. (1999). Analysis of imazethapyr in agricultural soils by ion exchange membranes and a canola bioassay. Commun. Soil Sci. Plant Anal., 30 (13\&14): 1831-1846

Vencill, W.K. (2002). Imazethapyr. In Herbicide handbook, $8^{\text {th }}$ ed. Weed Science Society of America: Lawrence, KS, 2002; 331-333.

Wyk, L.J.V. and Reinhardt, C.F. (2001). A Bioassay Technique Detects Imazethapyr Leaching and Liming-Dependent Activity. Weed Science Society of America, 15(1): 1-6 